\title{
Kategorija prostora u trinitarnoj teologiji Jürgena Moltmanna
}

\author{
MARIJA PEHAR* \\ • https://doi.org/10.31823/d.27.1.6 • \\ UDK: 27-144.896-05 Moltmann, J. • Izvorni znanstveni rad \\ Primljeno: 7. veljače 2018. • Prihvaćeno: 12. ožujka 2019.
}

Sažetak: Već zbog svoje konstitutivne funkcije unutar kategorije povijesti vrijeme je u židovsko-kršćanskoj tradiciji, pa onda i u kršćanskoj teologiji uvijek bilo veoma značajna i često promišljana tema, dok je kategorija prostora $u$ toj istoj teologiji ostajala više na periferiji interesa. Međutim u suvremenoj kršćanskoj teologiji primjećuje se probuđeni interes za tu kategoriju i nastojanje da ju se pokaže kao imanentno teološku kategoriju jer se u njoj prepoznaje egzistencijalno vjerničko pitanje ljudskoga traganja za Božjom nazočnošću i blizinom. Riječ je o pristupu u kojem se prostor promišlja kao relativnu veličinu u odnosu na Boga i čovjeka te s druge strane kao moguću oznaku samoga Božjega bića. S tom je argumentacijom pitanje prostora našlo svoje mjesto i u teološkim traganjima Jürgena Moltmanna. On se pita kako se prostor dade misliti

${ }^{*}$ Izv. prof. dr. sc. Marija Pehar, Katolički bogoslovni fakultet Sveučilišta u Zagrebu, Vlaška 38, 10000 Zagreb, Hrvatska, m.marijape@ gmail.com unutar bogoiskustva, odnosno kako misliti i razumjeti Boga ako pokušamo promišljati prostor u Bogu i Boga u prostoru. $S$ tim se pitanjem suočava kroz svoju vjerničko-teološku otvorenost svijetu (izrazito vidlivo unutar njegove teologije stvaranja), ali prije svega kroz dosljedan unutarnji razvoj svoje cjelokupne teološke misli koja svoje središte $i$ temelj nalazi u trinitarnoj teologiji, što se prepoznaje i prati u ovome radu. Neke polazne elemente za teološko promišljanje prostora naći će Moltmann u starozavjetnom razumijevanju Boga (»šekinah $\ll$, $\gg m a k o m \ll i ~ i z i m z u m \ll)$, što je predstavljeno u prvom dijelu ovoga rada, dok će temeljna uporišta za teološku interpretaciju kategorije prostora pronaći i razviti tek unutar trinitarnoga kršćanskoga nauka, što je izloženo u drugom, središnjem dijelu. Ovdje je pokazano kako Moltmann u otačkom nauku o perihorezi pronalazi glavno uporište za pozorno usredotočenje na kategoriju prostora kao teološku kategoriju, što je 
prepoznato kao temeljni zaokret unutar njegove teologije. Konačno, u trećem su dijelu iznesene dosljednosti koje iz Moltmannovih trinitarnih promišljanja prelaze u njegovu teologiju stvaranja, a kasnije i kršćansku eshatologiju, a u kojima izuzetnu važnost zauzima upravo promišljanje kategorije prostora. Ta se kategorija na neki način pokazala nosivom kategorijom njegove teologije, ali i crvenom niti koja u toj teologiji uvijek iznova izranja, iznutra je povezuje i u potpunosti prožima i određuje.

Ključne riječi: prostor, vrijeme, Trojstvo, trinitarna teologija, Moltmann.

\section{Uvod}

Dok je vrijeme, već kroz svoju konstitutivnu funkciju unutar židovstvu i kršćanstvu imanentne kategorije povijesti, u kršćanskoj teologiji značajna i često promišljana tema, za prostor kao teološku kategoriju može se reći da je ostao više drugorazredna tema. Takva teološka sklonost kategorijama vremena i prostora nalazi svoje argumente već u temeljima biblijsko-židovske i kršćanske tradicije.

Vjera izraelskih otaca, za razliku od njihova poganskoga okruženja, u svom je temelju bila opredjeljenje za živoga i osobnoga Boga koji se objavio kao ljubeći i nazočni, ali istodobno transcendentni i slobodni. U Izraelu je stoga kao temeljno Božje određenje trajno isticana distinkcija u odnosu na materijalni svijet: Bog je Bog, a svijet je njegovo stvorenje. Bog ne podliježe nužnosti kozmičkih datosti, prostornosti i materijalnosti. J. Ratzinger to će sažeto izraziti: »Nasuprot poganskoj tendenciji prema numen locale, prema mjesno određenom i ograničenom božanstvu, Bog otaca izražava sasvim drukčije opredjeljenje. On nije Bog jednoga mjesta, već Bog ljudi. (... ) Bog se promatra na osobnoj razini, razini ja-ti, a ne na razini prostornoga. ${ }^{1}$ Zbog te je snažne svijesti o Božjoj transcendentnosti biblijsko-židovska vjernička tradicija budno i trajno pazila da se, za razliku od poganskih religija, ni Božju osobu ni bogoštovni kult izravno ne veže uz manifestacije snaga i ritmova svijeta, prirode, nego uz Božju objavu koja se dogodila u povijesti. ${ }^{2}$ Sukladno tomu i teološki interes koji proizlazi iz te tradicije izvorno je više bio vezan

${ }^{1}$ J. RATZINGER, Uvod u kršćanstvo. Predavanja o apostolskom vjerovanju, Zagreb, 1988., 96.

${ }^{2}$ Zato se dogovoreno mjesto susreta Boga i čovjeka u židovstvu izvorno nije vezalo ni uz kakav zemaljski prostor niti je prostor mogao biti svet, nego je za taj susret bilo određeno sveto vrijeme, konkretno šabat, sedmi dan izdvojen od svih drugih i od svega drugoga da bi bio Bogu posvećen dan, sveti dan. Usp. M. PEHAR, Šabbat između vremena i prostora, u: M. CIFRAK, D. TOKIĆ (ur.), Da istina evandelja ostane kod vas (Gal 2,5), Zbornik u čast prof. dr. sc. Ivana Dugandžića, povodom 70. godine života, Zagreb, 2014., 423-440. I drugi značajniji židovski blagdani obilježeni su temporalno, imaju povijesno-spasenjsko značenje, tj. nisu spomen na mjesta nego na spasenjske događaje iz povijesti izabranoga naroda (primjerice: Pasha - spomen izlaska iz Egipta, Šebuoth spomen Sinajskoga zakona, Sukkoth - spomen boravka u pustinji nakon egipatskoga sužanjstva). Usp. A. REBIĆ, Biblijske starine, Zagreb, 1983., 199sl. 
uz kategoriju vremena kojoj se pripisivao duh i svijet duhovnoga iskustva, zazirući pomalo od kategorije prostora kojoj se više pripisivala materija i svijet stvari.

Takav temeljni starozavjetni stav ne će promijeniti ni neosporno teološko značenje Kovčega saveza i iz njega kasnije izvedeno teološko značenje hrama. Naime Sveti šator i u njemu prisutni Kovčeg zavjetni uvijek su držani više simbolom Božje nazočnosti u njegovu narodu nego stvarnim mjestom koje bi Jahvu zatvaralo i ograničavalo. U tom su se Kovčegu izvorno nalazile ploče Zakona, posuda s manom, Aronov štap i Mojsijevi spisi, a za vrijeme Salomona samo ploče Zakona. ${ }^{3}$ Sve to pokazuje da je Kovčeg zavjetni upućivao i podsjećao na Savez između Jahve i Izraela, dakle na Jahvinu obećanu i stvarnu, ali transcendentnu nazočnost u njegovu narodu. Ista će se bogoštovna praksa prenositi i na hram kao kasnije mjesto zavjetnoga Kovčega. Iskazivanje štovanja Kovčegu, odnosno hramskom Svetištu u kojemu je Kovčeg čuvan, čak i u vremenu poslije Salomona kada u Svetištu nije bilo Kovčega, bilo je podsjećanje na Savez i iskazivanje štovanja živomu Bogu, Stvoritelju i Gospodaru neba i zemlje, kojega se nikada ne može obuhvatiti ograničenošću i materijalnošću prostora. Iako je kasnije shvaćanje Božje nazočnosti u njegovu narodu u svijesti Židova neraskidivo povezano s hramom, taj hram, za razliku od poganskih hramova koji su držani obitavalištima bogova, nikada ne će biti smatran istinskim Božjim prebivalištem u smislu ograničavanja Jahve na krhkost i prolaznost materije, nego samo podnožjem njegovim nogama (usp. Iz 66, 1) i domom Njegovu imenu (usp. 2 Sam 7, 13), dakle ukazom na Jahvinu moć i slavu, mjestom bogoštovlja i iskazivanja časti Onomu koji nebo i zemlju nadilazi. Ratzinger će dobro primijetiti kako je hram $\mathrm{u}$ ispravnom teološkom shvaćanju uvijek smatran samo preslikom, dakle prilikom koja smjera $\gg s$ onu stranu same sebe $\ll$, dakle više prazninom nego prostorom. »Kovčeg se shvaćao kao prazno prijestolje na koje se spušta šekina - oblak Božje nazočnosti. $\ll^{4}$ Uostalom, upravo je proročka tradicija ona koja se protivila i Davidovoj nakani za gradnjom hrama kao Božjega trajnoga boravišta, upućujući na njezinu neprimjerenost božanstvenosti Jahvinoj, ističući je kao protivnu živomu Jahvi. Stoga će je prihvatiti samo kao kompromis i trajnu ugrozu istinskoga shvaćanja Božje transcendentnosti. Kasnije će novozavjetni mučenik Stjepan podsjetiti na tu neprimjerenost pomisli da bi materijalnost prostora mogla obuhvatiti živoga Boga: »Svevišnji u rukotvorinama ne prebiva $\ll(\mathrm{Dj} 7,48)$.

Shvaćanje objave kao povijesno-spasenjskoga događanja i bogoštovlja kao vjerničkoga razumijevanja, slavljenja i prihvaćanja spasenjskoga karaktera povijesnih događanja preuzet će dakle i kršćanstvo. Tako je politeistički interes za božanstva prostora konačno slomljen u židovsko-kršćanskom monoteizmu, osobito u njegovoj

\footnotetext{
${ }^{3}$ Usp. A. REBIĆ, Biblijske starine, 173.

${ }^{4}$ J. RATZINGER, Duh liturgije. Temeljna promišljanja, Mostar, 2001., 41. 65.
} 
proročkoj tradiciji, koja je, za razliku od poganskoga štovanja, navješćivala pravoga Boga, koji, unatoč tomu što je blizak čovjeku i narodu izabranja i trajno u tom narodu nazočan, ne boravi u ograničenom zemaljskom prostoru. To je simbolički došlo do izražaja u pozivu Abrahamovu, a svoj vrhunac doživjelo u Isusovu navještaju da se Bogu ne treba klanjati u hramu ili na nekom brdu, nego »u duhu i istini « (usp. Iv 4, 20-24). U njegovoj smrti i uskrsnuću kršćani će tako prepoznati dovršenje teologije hrama u njezinoj slici prilike i sjene, dakle u njezinoj prolaznosti i privremenosti, jer će razorenje Isusova zemaljskoga tijela smatrati i krajem zemaljskoga hrama. Isusovo je uskrsnuće početak novoga nerukotvorenoga hrama, ali to više nije materijalni prostor prilike i sjene, nego zbiljski prostor Duha i Istine koji stvarno omogućuje susret s Bogom. Zbog takvoga se shvaćanja, za razliku od poganstva za koje se smatralo da je obilježeno zarobljenošću materije i prostora, opredjeljenje židovstva i kršćanstva primarno za kategoriju vremena doživljavalo kao istinska oslobođenost za vrijeme. ${ }^{5}$

U takvom je shvaćanju oslobođenosti od prostora kao oslobođenosti od poganskoga, materijalnoga i profanoga i kršćanska teologija u svojim traganjima ostajala više okrenuta kategoriji vremena i povijesti kao vlastitom i primjernijem locusu. Naravno da će takvo stajalište imati svoje povijesne i kulturološke uvjetovanosti i oscilacije. Tako, kada bi životne okolnosti vjerničkoga života izravnije vodile u sunovrat prolaznosti i materijalnosti, u Crkvi su se javljale tendencije za istinskim oslobođenjem čovjeka za Boga i usmjeravanjem njegova pogleda na ono neprolazno i vječno, što je onda redovito pratila i propitkivala i kršćanska teologija kao sebi svojstveno traganje za pravim Bogom i načinima čovjekova susretanja s njim, za istinskim bogoštovljem oslobođenim svih zemaljskih idolopoklonstava, odnosno za pravim značenjem onoga $u$ duhu $i$ istini. Ipak, uz tu u teologiji nikad napuštenu dimenziju Bogu primjerene transcendentnosti, izražavanu pretežnim opredjeljenjem za kategoriju vremena kao primarno teološku kategoriju, u kršćanskoj teologiji, utemeljenoj na povijesnoj objavi Boga i inkarnaciji Logosa i njegova uskrsnuća tijelom, nikada nije u potpunosti izostalo okretanje i kategoriji prostora, kao kategoriji čovjeku i njegovoj stvarnosti primjerene materijalnosti i prolaznosti. Zanimljivo je da se to u suvremenoj zapadnoj teologiji (druga polovica 20. stoljeća) primjećuje osobito unutar protestantske teologije. ${ }^{6}$

\footnotetext{
${ }^{5}$ Usp. P. TILLICH, Der Widerstreit von Raum und Zeit. Schriften zur Geschichtsphilosophie, Stuttgart, 1963., osobito 140-148.

${ }^{6}$ Taj se naglašeni interes unutar protestantske teologije može razumjeti upravo iz povijesnoga konteksta te teologije. Vidi primjerice E. JOOSS, Raum, Eine theologische Interpretation, Gütersloh, 2005., J. M. LOZANO-GOTOR PERONA, Raum und Zeit in der evangelischen Theologie. Zur Behandlung und Verhältnisbestimmung beider Begriffe bei Wolfhart Pannenberg, Jürgen Moltmann und Christian Link, Hamburg, 2007.; U. BEUTTLER, Gott und Raum - Theologie der Weltgegenwart Gottes, Göttingen, 2010.; M. D. WÜTHRICH, Ein systematisch-theologischer Versuch, Raum zu denken, Göttingen, 2015.
} 
Pri tom je jasno da teologija ne promišlja prostor kao geometrijski pojam definiran koordinatama protežnosti i utemeljen na kvantitativnim mjerenjima, pa čak ni kao filozofski pojam apsolutnoga prostora, nego kao relativnu veličinu u odnosu na Boga i čovjeka te s druge strane kao moguću oznaku samoga Božjega bića. Ta se dakle pitanja u vremenu moderne i postmoderne ne postavljaju kao metafizička, nego kao egzistencijalna pitanja vjere, te upravo stoga promišljanje kategorije prostora postaje za kršćansku teologiju iznova veoma izazovno. ${ }^{7}$ Pitanje prostora kao Božjega obitavališta, odnosno pitanje Boga kao prostora za čovjeka otvara se kao egzistencijalno postavljeno pitanje ljudskoga spasenja. Sustavan teološki interes za kategoriju prostora pokazuje se tako kao teološki napor da se temeljni teološki sadržaj Božje objave suvremenom čovjeku pokaže bliskim i relevantnim, odnosno da mu se iznova približi egzistencijalna vrijednost biblijskoga iskustva Boga i Božje blizine. Na taj se način pitanje prostora kao teološke kategorije nametnulo i teološkim traganjima Jürgena Moltmanna. On se s njime susreće u svojoj vjerničko-teološkoj otvorenosti suvremenom svijetu i njegovim temeljnim pitanjima, ali dolazi do njega i unutarnjim razvojem svoje teološke misli, svojih promišljanja o Bogu, te stoga upravo iz promišljanja Božjega bića pokušava na njega odgovoriti.

Izričiti početak Moltmannove zaokupljenosti kategorijom prostora prepoznaje se u njegovoj teologiji stvaranja / teologiji stvorenoga ${ }^{8}$, kojoj su izravan povod i primarni kontekst izazovi ekološke krize osamdesetih i devedesetih godina. Tu krizu

\footnotetext{
${ }^{7}$ Može se navesti više razloga za to. Tako primjerice pod utjecajem suvremenih istraživanja svemira i spoznaja o njegovoj bezgraničnosti, te stoga i gubitkom apsolutne orijentacije unutar svemira, postaju uzdrmani tradicionalni izričaji o Božjoj onostranosti, o njegovoj nazočnosti gore na nebu. Filozofske formulacije o Božjoj svenazočnosti dovedene su u pitanje već iz unutarnje logike samoga mišljenja. Reći da je Bog svugdje ne znači mnogo jer je to gotovo isto kao i reći da je nigdje. A ono što nema mjesta ne može imati ni određeni bitak. Usp. E. JÜNGEL, Gott als Geheimnis der Welt. Zur Begründung der Theologie des Gekreuzigten im Streit zwischen Theismus und Atheismus, Tübingen 1977., 70. Osim tih imanentno teološki postavljenih pitanja, u vremenu moderne još snažnije odjekuje ljudsko iskustvo bogonapuštenosti i stravičnih ljudskih trpljenja prouzročenih grijehom i svjesnim odbacivanjem Boga (sve teži i razorniji ratovi, ekološko pitanje, pitanje nesagledive gladi i siromaštva, eksplicitna zlostavljanja, masovna razaranja i ubijanja ...) koja suvremenoga čovjeka uče da gotovo sigurno ima mjesta na kojima Bog nije (pitanje teodiceje). Gdje onda dakle Bog jest? Gdje ga se može susresti i iskusiti? Kamo treba ići da bi ga se susrelo? U sveukupnoj prijetnji suvremenoga ništavila i postmodernističke izloženosti, globalizacijske razgolićenosti i razotkrivenosti, ta pitanja dodatno dobivaju na svojoj važnosti.

${ }^{8}$ Usp. J. MOLTMANN, Gott in der Schöpfung. Ökologische Schöpfungslehre, Gütersloh, 1993. Njemački izraz Schöpfungslehre ne pravi diferencijaciju koju imamo u hrvatskom jeziku, stoga treba razumjeti kad se u hrvatskom tekstu u istom značenju nekad koristimo izrazom teologija stvaranja, a nekad izrazom teologija stvorenoga.
} 
on doživljava kao vrlo ozbiljno pitanje upućeno kršćanstvu i kršćanskoj teologiji. ${ }^{9}$ No, kao i kod svih drugih kontekstualnih izazova za teologiju, on i toj krizi i iz nje proizišlim pitanjima pristupa ponajprije kao teolog, što znači da glavna preokupacija njegovih promišljanja ostaje Bog. Stoga je razumljivo da i promišljanju iz te krize prepoznatoga i izazovnoga pitanja vezanoga uz kategoriju prostora pristupa primarno iz teološke perspektive te si kao temeljno polazište postavlja pitanje kako se prostor dade misliti unutar bogoiskustva, odnosno kako misliti i razumjeti Boga ako pokušamo promišljati prostor u Bogu i Boga u prostoru, što je nužno za biblijsko-kršćansko shvaćanje svijeta kao stvorenja. ${ }^{10}$ Stoga je sasvim razumljivo da promišljanje prostora koje se eksplicitno otvorilo unutar teologije stvorenoga on veže uz prethodno izneseni nauk o Bogu, odnosno sasvim konkretno uz kršćanski nauk o trojstvenom Bogu. Tako je njegova teologija stvaranja, koja je u jeku ekološke krize zadivila svijet, kao kršćanski pogled na svijet mogla proizići samo iz prethodno iznesenoga trinitarnoga nauka. ${ }^{11}$

\section{Polazna uporišta za kategoriju prostora u Moltmannovu nauku o Bogu}

Iznoseći u svom promišljanju Boga najprije neke elemente starozavjetnoga razumijevanja Boga, zanimljivo je da će Moltmann prva uporišta za kasnije teološko promišljanje prostora otkriti u tradicionalnom starozavjetnom nauku o šekinah i kabalističkom nauku o makom i zimzum, a daljim razvijanjem kršćanskoga nauka

\footnotetext{
${ }^{9} \mathrm{U}$ svojoj teologiji stvaranja, koju piše u jeku svijesti o ekološkoj krizi, Moltmann će primijetiti da je upravo jednostrano usmjerenje novovjeke teologije na antropocentrizam i ljudsku povijest kao svoju temeljnu paradigmu podupiralo pogubnu dihotomiju između povijesti i prirode (usp. isto, 149.). Svojom ekološkom teologijom stvaranja/stvorenoga on će stoga nastojati ljudsku povijest sinkronizirati s poviješću prirode (usp. isto, 148.), odnosno kategoriju vremena s kategorijom prostora. $\gg$ Ljudska povijest s prirodom nije se razumijevala kao dio povijesti prirode, nego se priroda razumijevala kao dio ljudske povijesti.« (Isto, 46.). Stoga je upravo u tom djelu i najvidljiviji Moltmannov interes za kategoriju prostora.

${ }^{10}$ Tako će Moltmann u kasnijim radovima sam izreći svoju tadašnju teološku preokupaciju pitanjem prostora. Usp. J. MOLTMANN, Gott und Raum, u: ISTI, Wissenschaft und Weisheit. Zum Gespräch zwischen Naturwissenschaft und Theologie, Gütersloh, 2002., 131-147., ovdje 132. Isti tekst u J. MOLTMANN, C. RIVUZUMWAMMI (ur.), Wo ist Gott? Gottesräume - Lebensräume, NeukirchenVluyn, 2002., 29-41.

${ }^{11}$ Ovdje prije svega mislimo na njegovo djelo Trinität und Reich Gottes. Zur Gotteslehre, Gütersloh, 1980., čiji će sadržaj obilježiti svu njegovu kasniju teologiju, ali i na elemente trinitarnoga nauka unutar same teologije stvaranja i u svim kasnijim teološkim osvrtima. Usp. primjerice J. MOLTMANN, In der Geschichte des dreieinigen Gottes. Beiträge zur trinitarischen Theologie, München, 1991. te ISTI, »Sein Name ist Gerechtigkeit.« Neue Beiträge zur christlichen Gotteslehre, Gütersloh, 2008., ovdje osobito $\gg$ Der drei-einige Gott $\ll$, 137-156.
} 
o Bogu koji je bitno trinitarni nauk, u otačkom će učenju o trinitarnoj perihorezi pronaći glavno uporište za kasnije snažnije usredotočenje na kategoriju prostora.

\subsection{MAKOM I ŠEKINAH}

Iako je svjestan starozavjetnog zaziranja od materijalnosti prostora u govoru o Bogu, vrlo je zanimljivo Moltmannovo zahvaćanje u starozavjetnu židovsko-kabalističku tradiciju rabinskoga govora o svetom prostoru (maqom qadosh), koji se onda primjenjuje i na Božju nazočnost koja se nastanjuje u hramu i Izraelu (šekinah $)^{12}$. Prema Maxu Jammeru, na kojega se Moltmann poziva ${ }^{13}$, makom (prostor) u palestinskom je židovstvu jedno od imena Božjih, kojim se označava beskonačno, ali neposredno mjesto. Ta se makom-tradicija poziva na knjigu o Esteri 4, 14. To je redak u kojem Mordokaj upozorava Esteru da će, ako ona ne iskoristi priliku za pomoć koja se od nje traži, sloboda i pomoć Židovima doći »s drugoga mjesta«, gdje se, pomno čuvajući Božju transcendentnost, pod mjestom jasno misli na samoga živoga Boga. Židovska je tradicija onda taj izraz primjenjivala i na sveto područje Božje - šekinah.

Pojam šekinah potječe iz vremena izraelskoga izgnanstva u Babilon i postegzilskih promišljanja o Bogu i označava Božje nastanjenje, Božju nazočnost i njegov boravak u narodu njegova izabranja. To nije jedno od imena Božjih, nego se tim pojmom potvrđuje Jahvina vjernost sklopljenom Savezu i njegovu obećanju izraelskom narodu da će biti njihov Bog i trajno boraviti među njima. ${ }^{14}$ To Božje nastanjenje i njegov boravak u narodu očituje se već prisutnošću zavjetnoga kovčega u šatoru koji je nomadski narod nosio sa sobom na svojim putovanjima, kralj ga David pre-

${ }^{12}$ Usp. J. MOLTMANN, Trinität und Reich Gottes, 42.

${ }^{13}$ Moltmann upućuje na Jammerovu knjigu Das Problem des Raumes. Die Entwicklung der Raumtheorien, izdanu 1960. godine u Darmstadtu. Usp. J. MOLTMANN, Gott und Raum, 136.

${ }^{14}$ Sukladno rabinskom nauku taj boravak Bezgraničnoga u materijalnom prostoru, Vječnoga u vremenitom nije moguće drukčije opisati nego kao Božje samoponiženje prema njegovu narodu i razumjeti kao prilagodbu vječne Božje ljubavi ljudskoj slabosti i nesavršenosti. Pojam šekinah obuhvaća tri aspekta: sadašnje nastanjenje Boga u Izraelu, obličje poniženja Vječnoga i udioništvo u slavi onoga koji dolazi. Unutar naglašene Božje transcendentnosti, primjerene starozavjetnom shvaćanju, tu je personificiranu nazočnost Boga u njegovu narodu, prema F. Rosenzweigu i židovskoj mistici, moguće misliti jedino kao svojevrsno samorazlikovanje unutar Boga samoga, odnosno kao jedan rascjep, rez unutar samoga Boga. Istina, taj rascjep ne dotiče božansku supstanciju jer to nije moguće, ali se pokazuje u Božjem životu i djelovanju. Usp. F. ROSENZWEIG, Der Stern der Erlösung, Frankfurt am Main, 1988., 455-456. Usp. također J. MOLTMANN, Trinität und Reich Gottes, 43-44. 
nio u Jeruzalem, Salomon mu sagradio hram, a kasnije u babilonskom je izgnanstvu šekinah i sama bila prognana zajedno s prognanim narodom. ${ }^{15}$

U šekinah-teologiji Moltmann uočava snažnu i djelotvornu pozadinu za oblikovanje novozavjetne kristologije i eksplikaciju trinitarne teologije. Nameće mu se usporedba s nekoliko novozavjetnih mjesta: »I Riječ je tijelo postala i nastanila se među nama $\ll($ Iv 1, 14); u Kristu »tjelesno prebiva sva punina božanstva $\ll(K o l ~ 2,9)$, Duh Sveti stanuje u našim tijelima i u zajednici Kristovoj kao u jednom hramu (1 Kor 6, 19). Riječje o inkarnaciji Riječi i inhabitaciji Duha Svetoga, koje se kao i šekinah temelje na kenozi Božje ljubavi. Moltmann će u svojim kasnijim eshatološkim promišljanjima primijetiti da ta Božja nastanjenja Sina i Duha upućuju, konačno, i na eshatološku nazočnost bezgraničnoga i vječnoga Boga u ograničenom stvorenju njegove ljubavi prema kojoj će Bog biti »sve u svemu « $\left(1\right.$ Kor 15, 28). ${ }^{16}$ Ta će eshatološka promišljanja svoj vrhunac dobiti u šabat-teologiji, koju Moltmann razvija kao konačno povezivanje vremena i prostora, izlažući šabat kao vrijeme koje iskoračuje iz vremenitosti i, suspendirajući vremenitost, participira na Božjoj vječnosti kao intenzivnoj Božjoj nazočnosti te tako prelazi u kategoriju apsolutnoga prostora kao životnoga prostora stvorenja unutar smoga Boga. ${ }^{17}$

Starozavjetna misao o makom i šekinah postaje za Moltmanna izravno uporište za teološko promišljanje prostora, odnosno otvorena mogućnost promišljanja Boga kao prostora svoga stvorenja i stvorenja kao prostora Božjega. Govor o Bogu kao svetom apsolutnom prostoru (maqom qadosh) bit će za Moltmanna uporište za promišljanje stvorenja u Bogu. Bez ograničenja makom je primjenjivan kao pojam za Božju svenazočnost koja sve obuhvaća, kako je opisano u Ps $139 .{ }^{18} \mathrm{U}$ smislu nazočnosti ograničene na stvorenje Boga se shvaća kao makom svijeta. Iz toga dvostrukoga shvaćanja Jammer će izvući teološko pitanje: »Ne znamo je li Bog prostor svoga svijeta ili je njegov svijet njegov prostor «, kao i rabinski odgovor: »Gospodin je obitavalište svoga svijeta, ali njegov svijet nije njegovo obitavalište. ${ }^{19}$ Ipak, Moltmann će na temelju Božje nazočnosti nastanjene u hramu i Izraelu (šekinah) u svojoj teologiji stvaranja govoriti i o svijetu kao Božjem obitavalištu. ${ }^{20} \mathrm{Za} \mathrm{njega} \mathrm{je}$

\footnotetext{
${ }^{15}$ Usp. J. MOLTMANN, Erfahrungen theologischen Denkens. Wege und Formen christlicher Theologie, Gütersloh, 1999., 276.

${ }^{16}$ Usp. isto, 277.

${ }^{17}$ Više u: M. PEHAR, Šabbat između vremena i prostora, 432-438.

$18 \gg$ Kamo da idem od Duha tvojega i kamo da od tvog lica pobjegnem? / Ako se na nebo popnem, ondje si, ako u Podzemlje legnem i ondje si. / Uzmem li krila zorina pa se naselim moru na kraj / i ondje bi me ruka tvoja vodila, desnica bi me tvoje držala.« (Ps 139, 7-10)

${ }^{19}$ Citirano prema J. MOLTMANN, Gott und Raum, 136.

${ }^{20}$ Usp. J. MOLTMANN, Gott in der Schöpfung, 29.
} 
svijet ljubljeno Božje stvorenje, koje Bog svojom nazočnošću nastanjuje i u kojem stoga boravi. ${ }^{21}$ Naravno, tek u svojoj eshatološkoj eksplikaciji dovršenja stvorenja (creatio nova) pokazat će ta misao svoje puno značenje. »Božanska tajna stvorenja je šekinah (Božje nastanjenje), a cilj šekinah je u tomu da cjelokupno stvorenje učini Božjom kućom. ${ }^{22}$

\subsection{ZIMZUM-NAUK}

Još je jedno mjesto u kojem će Moltmann pronaći uporište za kasniji razvoj kategorije prostora kao teološke kategorije preuzeto iz židovske tradicije. Riječ je o kabalističkom zimzum-nauku Issaka Lurie, u koji Moltmann zahvaća u kontekstu promišljanja stvaranja svijeta kao čina koji se tiče unutarnjega božanskoga života. ${ }^{23}$

Na pitanje kako je moguće unutar poimanja svemogućega i svenazočnoga Boga uopće misliti nešto izvan njegova bića, izvan njegova božanstva, iz čega bi onda mogla izići opera ad extra, taj nauk odgovara da se u Bogu koji je ljubav događa svojevrsna kontrakcija, samoograničenje, samopovlačenje u samoga sebe da bi Bog stvorenju svoje ljubavi omogućio prostor, vrijeme i slobodu. Tako je Božje stvarateljsko djelovanje ad extra moguće tek nakon što je Bog ad intra stvorio »neke vrste mistični praprostor $\ll^{24}$, prostor ispražnjenosti od samoga sebe (nihil), kao pretpostavku za stvaranje. »Prostor koji nastaje Božjim samoograničenjem i biva slobodan u doslovnom je smislu bogonapušteni prostor. $\ll^{25}$ Onaj nihil iz kojega Bog stvara i od čije će prijetnje trajno čuvati život svoga stvorenja to je bogonapuštenost, pakao, vječna smrt. Naravno, nihil će taj prijeteći karakter dobiti tek privolom stvorenja na njega, što Moltmann naziva grijehom i bezbožnošću. Omogućivanjem stvaranja kroz to Božje samoograničenje nihil još nema takav uništavajući karakter.

${ }^{21}$ Knjiga u kojoj iznosi teologiju stvorenoga stoga i nosi naziv Bog u stvorenju. Isti se sadržaj označava i podnaslovom knjige Ekološka teologija stvaranja, gdje se pridjevom ekološka upućuje ne samo na relevantnost te teologije pred postojećom ekološkom krizom nego na etimološkom tragu značenja riječi oikos - 'kuća', Moltmann želi ukazati da je stvorenje kuća i obitavalište Božje. Usp. isto, 21.

${ }^{22}$ Isto, 12.

${ }^{23}$ Stoga je razumljivo da je taj nauk Moltmann izložio najprije u okviru svoje trinitarne teologije (Trinität und Reich Gottes, 123-127.), a zatim mu se ponovno vraća govoreći o prostoru stvorenja unutar teologije stvaranja (Gott in der Schöpfung, 98-102.). U okviru teologije stvaranja podsjeća Moltmann da je taj nauk o Božjem samoograničenju već prije prodro u kršćansku teologiju te spominje imena: Nicolaus von Cues, J. G. Hamann, Fr. Oetinger, F. W. J. Schelling, A. von Oetingen, E. Brunner i druga. Usp. J. MOLTMANN, Gott in der Schöpfung, 100.

${ }^{24}$ J. MOLTMANN, Trinität und Reich Gottes, 125.

${ }^{25}$ J. MOLTMANN, Gott in der Schöpfung, 100. 
On je ispražnjenost da bi stvorenju bila omogućena samostojnost izvan Boga, izvan Božjega bića, ali s time je stvorenju dana i mogućnost poništavajućega ništavila. ${ }^{26}$

Tom stvarateljskom djelovanju prethodi Božja stvarateljska odluka koja je čin njegove volje. ${ }^{27}$ Iako stvaranje nastaje kao čin Božje volje, jasno je da je ono prije svega posljedica Božje unutartrojstvene ljubavi. »Trojstveni odnos Oca, Sina i Duha Svetoga toliko je širok, da cijelo stvorenje u njemu može naći prostor, vrijeme i slobodu. $\ll^{28} \mathrm{Ta}$ se ljubav prema stvorenju od početka pokazuje kao kenotička ljubav jer, da bi stvorenju omogućio bitak, Bog svoj bitak najprije mora povući, ograničiti. Dakle prije nego je actio Dei (Božja djelatnost) stvaranje je passio Dei (Božje trpljenje $)^{29}$, prije nego je čin Božje volje stvaranje je posljedica Božje ljubavi. Da bi se moglo govoriti o creatio ex nihilo, najprije se mora govoriti o creatio ex amore. Ili: creatio ex nihilo moguće je misliti jedino kao creatio ex amore.

Zahvaćanjima u starozavjetno-kabalistički nauk Moltmann pokazuje kako je već unutar strogo monoteističkoga razumijevanja Boga moguće Boga misliti s jedne strane kao životni prostor i obitavalište svojega stvorenja, a s druge strane kao onoga koji ujedno i sam boravi u stvorenju svoje ljubavi. No dublji teološki razlog toga obostranoga nastanjenja pronalazi on tek u Božjem unutartrojstvenom biću. Na taj način mišljena, prostornost $u$ Bogu postaje još diferenciranija i zanimljivija. ${ }^{30}$

\section{Božje trojstveno jedinstvo - perihoreza}

Moltmannovo polazište u razvoju trinitarne teologije jest nastojanje da se razumijevanje Božjega bića ne izvodi primarno iz filozofskih premisa i ontoloških promišljanja o bitku, nego da se Božje biće misli dosljedno novozavjetnom svjedočanstvu i kršćanskom iskustvu vjere te upravo na tom putu otvara on i nove pretpostavke za kršćansko okretanje kategoriji prostora. Naime on primjećuje da novozavjetno bogoiskustvo nadilazi staru šekinah-teologiju ako Božje nastanjenje u svijetu sada u tom novozavjetnom iskustvu dobiva konkretno obličje, konkretno tijelo, konkretno ime: Isus iz Nazareta. ${ }^{31}$ Kako je razlikovanje Oca, Sina i Duha Svetoga ono koje bitno obilježava božansku stvarnost iznesenu kroz novozavjetno svjedočanstvo i izlaganje Božjega djelovanja u povijesti kao trojstvenoga djelovanja, Moltmannov je stav da ono treba postati i temeljno uporište u izlaganju kršćanskoga nauka o

\footnotetext{
${ }^{26}$ Usp. isto, 100-101.

${ }^{27}$ Usp. isto, 92-98.

${ }^{28}$ J. MOLTMANN, Trinität und Reich Gottes, 124.

${ }^{29}$ Usp. isto, 125.

${ }^{30}$ Usp. J. MOLTMANN, Gott und Raum, 137.

${ }^{31}$ Usp. isto, 142.
} 
Bogu (teologije). A to, prema njegovu zaključku, nužno zahtijeva da se pri tom ne pođe od Božje jednosti, nego od njegove trojstvenosti te da upravo trojstvenost bude temeljno kršćansko određenje pojma Boga i Božje jednosti. Moltmann to, zajedno s mnogim drugim suvremenim teolozima, čini preuzimanjem i oživljavanjem otačkoga pojma perihoreze kao temeljne oznake unutartrojstvenoga zajedništva.

Pojmom perihoreze, koji je u teologiju ušao iz stoičke fizike, u trinitarnoj se teologiji označava »međusobno prožimanje božanskih osoba i prebivanje jedne u drugoj $\ll{ }^{32}$, pri čemu se ističe da su Otac, Sin i Duh Sveti potpuno jedno u jedinstvenoj biti i potpuno jedan u drugome bez miješanja ili dijeljenja. Utemeljenje tomu razmišljanju jest ivanovski izraz: »Bog je ljubav« (Iv, 1, 8.16), kao i Isusove riječi: $\gg$ Ja sam u Ocu i Otac u meni.«(Iv 10, 38; 14, 11) Trojstvo se tim izrazom predstavlja kao savršeno zajedništvo ljubavi koja se među osobama izlijeva i priopćava.

Perihoretsko shvaćanje božanskoga Trojstva ukazuje na činjenicu da Bog nije monolitna jednost, nego dinamično jedinstvo i životno zajedništvo, odnos ljubavi. Naravno, perihoretskim promišljanjem Božje jednosti ne dovodi se u opasnost monoteizam, nego ga se definira kao specifičan kršćanski monoteizam, kao savršeno zajedništvo trojstvene ljubavi. Otac, Sin i Duh Sveti nisu dakle jedan, nego jedno u njihovu međusobnom prožimanju i nastanjenju (»Unum in trinitate «, a ne $\gg$ Unus in trinitate $\ll)^{33}$. $\gg$ Perihoreza božanskih osoba opisuje njihovu jednost na trojstven način, ne metafizičkim pojmovima božanske supstancije ili apsolutnoga subjekta. ${ }^{34}$

Kroz povijest je latinski prijevod circumincessio, kojim se označava više dinamički vid (incedere) bio pridržan kristološkoj ${ }^{35}$, dok se izrazom circuminsessio (od insedere), kojim se označava više statični vid, mirovanje i boravak jednoga u drugom, koristilo za trinitarnu perihorezu. Moltmann primjećuje kako unutartrojstvenoj perihorezi pripadaju oba značenja toga izraza jer je unutartrojstveni božanski život trajno dinamičko prožimanje, trajno ulaženje jedne božanske osobe u drugu, ali i trajno obitavanje jedne u drugoj. Poziva se pritom na Firentinski koncil i njegove riječi: »Zbog tog jedinstva Otac je čitav u Sinu, čitav u Duhu Svetom; Sin je čitav

${ }^{32}$ M. PEHAR, Perihoreza - stari pojam i njegova nova karijera, u: Obnovljeni život 66(2011.)2, 219231., ovdje 220. Više o perihorezi vidi također C. SORČ, Entwürfe einer perichorestischen Theologie, Münster, 2004.

${ }^{33}$ Usp. G. GRESHAKE, Der dreieine Gott. Eine trinitarische Theologie, Freiburg, 52007., 64.

${ }^{34}$ J. MOLTMANN, Erfahrungen theologischen Denkens, 277.

${ }^{35}$ Kristološkom se perihorezom označava prožimanje bez miješanja dviju naravi u Kristu, odnosno »savršeno sjedinjenje božanske i ljudske naravi u Kristu, pri kojemu svaka ostaje u potpunosti ono što jest $\ll$. M. PEHAR, Perihoreza - stari pojam i njegova nova karijera, 222. 
u Ocu, čitav u Duhu Svetom; Duh Sveti je čitav u Ocu, čitav u Sinu. Niti jedan drugom ne prethodi niti vječnošću, niti odskače veličinom, niti nadilazi vlašću. $\ll^{36}$

Za Moltmannovo je promišljanje karakteristično da on razlikuje konstitutivnu razinu Trojstva i razinu trojstvenih odnosa. Konstitutivna razina Trojstva oblikovana je klasičnim izvornim relacijama i samo i isključivo na toj razini može se, prema Moltmannu, govoriti o monarhiji Oca. Na razini odnosa život trojstvenih osoba opisan je perihorezom. Perihoretski gledano, božansko zajedništvo nije hijerarhijsko zajedništvo. Štoviše, pečat jedinstva u Trojstvu nije monarhija Oca, nego upravo perihoreza božanskih osoba. Božansko jedinstvo nije dakle preduvjet božanskoj trojstvenosti, nego je ono oblikovano međusobnim odnosima trojstvenih osoba. Ta je perihoretska forma božanskoga jedinstva, prema Moltmannu, jedini zamisliv trojstveni pojam jedinstva jer su jedinstvo i trojstvenost tako kombinirani da se ne mogu jedno na drugo reducirati.

Moltmann će naglasiti da ono što je prema pojmu perihoreze odlučujuće unutar Trojstva nije ni supstancija boštva ni identitet osoba, nego njihova sunazočnost jedne u drugoj. U Bogu se ne može polaziti od supstancije boštva, nego od osobe Oca. A Otac je Otac samo ako je Otac Sina. Tako Božje biće (božanski bitak) jest nutarnje zajedništvo božanskih osoba. Štoviše, Božje biće nema drugoga ontološkoga sadržaja nego ako je ljubav i zajedništvo Oca, Sina i Duha Svetoga. Kršćansko se iskustvo Boga tako uvijek svodi na riječi Grgura Nazijanskog: »Kada velim Bog, mislim na Oca i Sina i Duha Svetoga. $\ll^{37}$ Tek se tako može razumjeti riječ Objave: $\gg$ Bog je ljubav« $(1 \mathrm{Iv} 4,16)$, ili kasnije izrečena riječ sv. Augustina: »Vides trinitatem, si caritatem vides $\ll-$ Vidiš Trojstvo, ako vidiš ljubav. ${ }^{38}$

Jasno da perihoretsko promišljanje božanskoga jedinstva vodi i novom shvaćanju trinitarnoga pojma osobe. Na perihorezu se ne može primijeniti stara Boetijeva definicija prema kojoj bi osoba bila »individualna supstancija razumne naravi« (individua substantia naturae rationalis). Perihoretski bi pojam osobe nadilazio i komunitarni pojam (persona in communione) jer bi trebao biti oblikovan upravo izmjeničnim nastanjenjem Oca, Sina i Duha Svetoga. »U Sinu i Duhu dolazi Otac sebi samomu i biva sam sebe svjestan. U Ocu i Duhu dolazi Sin sebi samomu i biva sam sebe svjestan. U Ocu i Sinu dolazi Duh Sveti sebi samomu i biva sam sebe svjestan. $\ll{ }^{39}$ Nije dakle jedan subjekt u Trojstvu onaj koji predstavlja jedinstvo,

\footnotetext{
${ }^{36}$ H. DENZINGER, P. HÜNERMANN (ur.), Zbirka sažetaka vjerovanja, definicija i izjava o vjeri $i$ ćudoredu, Đakovo, 2002., br. 1331.

${ }^{37}$ Oratio, 45,4 (PG 36, 628 C). Citirano prema G. GRESHAKE, Der dreieine Gott, 87.

${ }^{38}$ AURELIJE AUGUSTIN, Trojstvo, M. Mandac (ur.), Split, 2009., VIII, 12.

${ }^{39}$ J. MOLTMANN, Erfahrungen theologischen Denkens, 280.
} 
nego je to trojstveni intersubjektivitet, koji nazivamo perihorezom. Odatle će Moltmann zaključiti da »ako je perihoreza ona koja oblikuje trojstveno jedinstvo, ona također vodi i razlikovanju među trojstvenim osobama $\ll .{ }^{40}$ Prema perihoretskom shvaćanju uvijek je treća osoba važna za konstituiranje osobnosti drugih dviju jer ostvarenjem različitih odnosa prema drugim dvjema osobama upravo ona te dvije osobe i povezuje i razlikuje. »Otac čini razliku između Sina i Duha, jer on ima različite odnose prema Sinu i prema Duhu; Sin čini razliku između Oca i Duha, jer on iskazuje različite odnose prema Ocu i Duhu; Duh konačno čini razliku između Oca i Sina na temelju različitih odnosa prema Ocu i Sinu. $\ll^{41}$ Moltmann naglašava da je takav perihoretski pojam osobnosti osobito važan za pročišćenije poimanje osobnosti Duha Svetoga, pomalo zapostavljeno unutar zapadnoga kršćanstva. Duh Sveti, tako kaže Moltmann, nije samo »Duh Očev《i i $\gg$ Duh Kristov«, nego »Bog Duh Sveti k koji je sučelice Bogu Ocu i Bogu Sinu, koji se ne samo od njih prima, kako se to tradicionalno naglašavalo, nego se također u potpunosti i njima daruje i potpuno je u njima kao što su i oni u njemu. ${ }^{42}$

Trojstvene osobe žive u takvom zajedništvu ljubavi da ne žive samo jedna uz drugu i jedna za drugu, nego svaka osoba Trojstva egzistira, boravi i kreće se u drugim dvjema i istovremeno sebe otvara i daruje za prostor gibanja, boravište i životni prostor drugim dvjema. »Svaka osoba snagom perihoreze čini sebe nastanjivom za druge dvije. ${ }^{43}$ Otac, Sin i Duh Sveti žive jedan s drugim, jedan za drugoga, ali i jedan u drugome. Jedinstvo je u Trojstvu međusobno darivanje pojedinih osoba za nastanjenje drugim dvjema i primanje dara nastanjenosti u drugim dvjema, a osobe su životni prostori, stanovi jedna drugoj, tako da se može govoriti ne samo o trinitarnim osobama nego i o trinitarnim prostorima. ${ }^{44}$ Svaka se osoba Trojstva otvara u široki prostor i dom spreman za druge dvije osobe te je svaka aktivna i pasivna $u$ isto vrijeme, daruje se i druge prima. Otvara sebe za prostor obitavanja drugim dvjema i prihvaća druge dvije kao prostor svoga obitavanja. Božje se biće tako u cjelini pokazuje kao široki i otvoreni prostor ljubavi.

\section{Kategorija prostora u dosljednostima trinitarne perihoreze}

Nauk o Bogu, osobito perihoretsko promišljanje Trojstva kao unutarbožanskih trinitarnih prostora bit će stoga za Moltmanna uporište da dosljedno razvije kr-

\footnotetext{
${ }^{40}$ Isto.

${ }^{41}$ Isto.

${ }^{42}$ Usp. isto.

${ }^{43}$ J. MOLTMANN, Gott und Raum, 138.

${ }^{44}$ Usp. J. MOLTMANN, Erfahrungen theologischen Denkens, 279.; J. MOLTMANN, Gott und Raum, 139.
} 
šćansku teologiju stvaranja, a kasnije i kršćansku eshatologiju, u kojima će cjelovito razviti teološko promišljanje kategorije prostora.

\subsection{Perihoreza i teologija stvaranja}

Kako je Božji nutarnji život, odnosno trojstvena perihoreza, prema kršćanskom shvaćanju život savršene sebedarne ljubavi obilježen $\gg$ trajnim 'ostavljanjem mjesta' drugome, putem vječnog sebedarja: Otac 'daje mjesta' Riječi, a obojica 'daju mjesta' Duhu Svetomu $\ll^{45}$, za Moltmanna je nezamislivo da bi se takvo neograničeno darivanje sebe kao mjesta za drugoga moglo misliti kao u sebi zatvorena razmjena. Tako, perihoretski shvaćeno, božansko jedinstveno zajedništvo otvara mogućnost da se Boga ne misli kao u sebe zatvorenu monadu, nego kao otvoreno i pozivajuće jedinstvo. ${ }^{46}$ To je za Moltmanna polazište za teološko promišljanje u kojem on nastanak i egzistenciju stvorenja promatra kao odsjaj unutarbožanskoga života ljubavi i darivanja.

Stvaranje, otkupljenje (inkarnaciju) i prosvjetljenje svijeta promišlja on, kako smo već vidjeli, ne samo kao opera trinitatis ad extra, nego sukladno unutartrojstvenom događanju ljubavi i kao opera trinitatis ad intra. Pita se ne samo što Bog znači za svijet nego i što stvorenje znači za Boga. ${ }^{47}$ Zaključuje da Bog koji stvara iz ljubavi ljubi svoje stvorenje i čezne za ljubavlju svoga stvorenja. A budući da je imanentno Trojstvo međusobna inegzistencija, ekonomijsko je Trojstvo očitovanje i preslikavanje istih unutartrojstvenih odnosa na stvorenje njegove ljubavi. Stoga Moltmann u svojoj ekološkoj teologiji stvaranja sveukupno stvorenje gleda kao stvarnost koja po stvorenjskoj ljubavi ima svoje mjesto (oikos) u Bogu i istovremeno je samo žuđeno mjesto Božjega prebivanja. ${ }^{48}$ Bog u stvorenju i stvorenje u Bogu.

Pri tom Moltmann, naravno, ne miješa Boga i svijet te razlikuje nastanjenje Boga u stvorenju i nastanjenje stvorenja u Bogu jer se ne mogu staviti na istu razinu. »Bog nastanjuje svijet na Božji način, svijet nastanjuje Boga na način svijeta. $\ll^{49}$ On se ovdje koristi višestrukim značenjem pojma perihoreze i snagom toga izraza da izrazi ne samo savršeno jedinstvo i zajedništvo različitih unutar iste naravi (trinitarna perihoreza) nego i zajedništvo bez dijeljenja i miješanja među različitim naravima jedne osobe (kristološka perihoreza). »Dok tri božanske osobe svoju perihorezu

\footnotetext{
${ }^{45}$ E. C. RAVA, Stvaranje, u: A. STARIĆ (ur.), Enciklopedijski teološki rječnik, Zagreb, 2009., 11061108., ovdje 1108.

${ }^{46}$ Usp. J. MOLTMANN, Trinität und Reich Gottes, 110-112.

${ }^{47}$ Usp. isto, 113.

${ }^{48}$ Usp. isto, 114.

${ }^{49}$ J. MOLTMANN, Gott in der Schöpfung, 160. Moltmann odbacuje prigovor panteizma (pan-theismus) te govori o panenteizmu (pan-entheismus). Usp. isto, 114-115.
} 
čine kroz homolognu ljubav, povezuju se božansko i ljudsko u Bogočovjeku snagom heterologne ljubavi. $\ll^{50}$ Upravo tu kristološku formu perihoreze primjenjuje Moltmann na međusobno prožimanje Boga i svijeta. Bog je prostor svoga stvorenja, ali je i stvorenje prebivalište Božje. Riječ je o međusobnom nastanjenju nejednakih koji se međusobno prožimaju bez da se poništavaju. Pri tom za Moltmanna to nije spekulacija, nego svakodnevno bogoiskustvo. »'Tko ostaje u ljubavi, ostaje u Bogu i Bog ostaje u njemu.' (1 Iv 3, 16) Mi ostajemo na ljudski način u Bogu: Bog postaje naš životni prostor, obitavalište i prostor slobode. Bog ostaje na božanski način u nama: mi postajemo njegovim životnim prostorom, obitavalištem i prostorom slobode: Ubi caritas et amor gaudet, ibi Deus est. $\ll^{51}$

Perihoretski shvaćeno, Trojstvo, koje je unutarnje prožimanje osoba kao otvorenih prostora jedne za drugu, ujedno je i prema van otvoren prostor koji, jer je savršena ljubav, k sebi i u sebe poziva i svoje stvorenje. Na to upućuju Isusove riječi: »Kao što si ti, Oče, u meni i ja u tebi, tako neka i oni budu u nama.« (Iv 17, 21) Unutartrojstvena ljubav otvorena za stvorenje pokazuje se tako kao kenotička ljubav te time odgovara unutarnjem zahtjevu ljubavi koja uvijek teži rastu i prelijevanju izvan i preko same sebe (u čemu Moltmann prepoznaje sličnost sa zimzum-naukom). Stoga i nastanjenje stvorenja u Bogu odgovara i nastanjenju Boga u stvorenju. Poziv čovjeku za nastanjenjem u Bogu odgovara i nutarnjoj čežnji Boga za nastanjenjem u čovjeku kao stvorenju svoje ljubavi. $\gg$ Ako me tko ljubi, čuvat će moju riječ pa će i Otac moj ljubiti njega i k njemu ćemo doći i kod njega se nastaniti.«(Iv 14, 23) Perihoreza se tako za Moltmanna pokazuje kao način koji dopušta misliti stvorenje kao prostor Božji i Boga kao životni prostor stvorenja.

\subsection{ESHATOLOŠKA PERIHOREZA}

Konačno, Božje jedinstvo, promišljano kao perihoretsko zajedništvo, u Moltmannovoj se teologiji pokazuje ne samo kao teološki nego i kao soteriološki pojam. Na temelju svega izrečenoga on razvija i perihoretsku eshatologiju u kojoj eshatološko dovršenje promišlja kao konačno i savršeno nastanjenje Boga u njegovu stvorenju i stvorenja u Bogu. ${ }^{52}$

Predajom Sina u smrt i izručenjem bogonapuštenosti na križu (Isusov vapaj »Bože moj, Bože moj, zašto si me ostavio «, Mt 27, 46) ušao je Bog u ono ništavilo, nihil, iz kojega je stvorenje prvotno izvedeno u svoj bitak. Svojim ulaženjem on to ništavilo prožima i ispunja ga sobom, svojom boli, ljubavlju prema stvorenju i vlastitim

\footnotetext{
${ }^{50}$ J. MOLTMANN, Erfahrungen theologischen Denkens, 277.

${ }^{51}$ J. MOLTMANN, Gott und Raum, 144.

${ }^{52}$ Ovdje se prije svega misli na njegovo djelo Das Kommen Gottes. Christliche Eschatologie, Gütersloh, 1995., osobito IV. poglavlje $\gg$ Neuer Himmel - neue Erde, Kosmische Eschatologie «, 285-349.
} 
iskustvom smrti. Bog ulazi u ljudsku prazninu bogonapuštenosti grijeha i smrti (silazak nad pakao) i time što u nju ulazi nadmoćno je pobjeđuje. ${ }^{53}$ Križ Kristov kao novo središte svijeta postao je tako poništenje ništavila iz kojega je svijet stvoren i nanovo mu otvara pristup onom iskonskom prostoru ljubavi za koji je stvoren. $U$ prostor Oca, u kojemu Sin odvijeka boravi i u koji nakon uskrsnuća ponovno ulazi, uvest će po Duhu Svetom i one koji su kao njegova braća sinovi Oca. »Idem pripraviti vam mjesto da i vi budete gdje sam ja. U kući Oca moga ima mnogo stanova.« (Iv 14, 2-3)

Po križu i uskrsnuću započelo je tako eshatološko vrijeme, a stvorenju je otvoren i eshatološki prostor. Otvorena je mogućnost vječne perihoreze Boga i njegova stvorenja. Prema u Kristu utemeljenoj eshatološkoj nadi cjelokupno će stvorenje biti »izvedeno u bezgranična prostranstva (usp. Job 36, 16) vječnoga Božjega života, a trojstveni će Bog nastaniti svoje prosvijetljeno stvorenje i sam u njemu naći svoj počinak..$^{54}$

Kršćanska eshatologija ukazuje na to da je pravi smisao i cilj stvorenja da bude prostor u kojem će Bog obitavati. »Sveti grad, novi Jeruzalem, (...) opremljen poput zaručnice koja je nakićena za svoga muža « (Otk 21,2), zapravo je, prema povezivanju s kabalističkom teologijom, opis vječnoga Šabata (usp. Heb 4, 9-10) u kojem će se Bog konačno združiti sa svojom Šekinah i otpočinuti u svom stvorenju. $\gg E v o$ stana Božjeg medu ljudima! On će stanovati s njima: oni će biti njegov narod, i on sam, Bog bit će s njima.« (Otk 21,3) To obećanje konačnoga Božjega počinka (prema rabinima i Božjega samootkupljenja) otvara nadu i ljudskoj čežnji za ostvarenjem životnoga prostora u trajnoj Božjoj nazočnosti u vječnom Šabatu. U vječnom će Jeruzalemu Bog sam biti zaštićeni životni prostor svoga stvorenja. »Hrama ne vidjeh u njemu. Njegov hram, naime, jest Gospodin, Bog Svemogući.« (Otk 21, 22). Naravno, početak ispunjenja eshatološkoga obećanja danoga Izraelu kršćanska vjera prepoznaje u Kristu, ako je Bog u njemu bespridržajno otvorio prostor svoga nutarnjega života za čovjeka. »Budući da u njemu stanuje stvarno (tjelesno) sva punina božanstva ... « $(\mathrm{Kol} 2,9)$ postaje On stvarnim mjestom i ponuđenom mogućnošću susreta Boga s čovjekom i Boga kao čovjekova životnoga prostora.

Po svome Sinu i Duhu boravi Bog već sada u svome stvorenju (incarnatio i inhabitatio), ali i vodi stvorenje konačnome dovršenju, kad će ono biti savršeni hram i

\footnotetext{
${ }^{53}$ Usp. J. MOLTMANN, Trinität und Reich Gottes, 123-125.; ISTI, Gott in der Schöpfung, 103-104.

${ }^{54} \mathrm{Za}$ to promišljanje Moltmann uporište pronalazi u židovskom poimanju Šabata, prema kojemu stvorenje nalazi svoj mir i svoje otkupljenje u Bogu, ali i Bog ulazi u svoj vječni počinak sjedinjujući se sa stvorenjem svoje ljubavi. Tako prema rabinskoj teologiji »cilj vremena nije i ne može biti unutar njega samoga, nego izvan njega u mesijanskom novom stvaranju. Stvorenje je stvoreno u vremenu, ali će biti dovršeno u prostoru «. M. PEHAR, Šabbat između vremena i prostora, 437.
} 
boravište Božje (1 Kor 15, 18: Bog sve u svemu). Osobito u sadašnjem nastanjenju Duha Svetoga u srcima vjernih (inhabitatio Spiritus Sancti in corde) prepoznaje Moltmann zalog eshatološkoga nastanjenja Boga u stvorenju. ${ }^{55}$ Tako eshatološkom perihorezom ulazi Bog u svoj počinak u stvorenju (stvorenje kao hram), ali i uvodi svoje stvorenje u zaštićeni prostor svoga nutarnjega života (pobožanstvenjenje). ${ }^{56}$ Tako će izvorno creatio ex nihilo prijeći u eshatološko annihilatio nihili, definitivno dokinuće svake prijetnje ništavila te otvaranje nove i konačne kategorije otkupljene prostornosti u samome Bogu koji je svome stvorenju istinski dom. Time Moltmann naglašava kako kršćanska eshatologija, odnosno u njoj utemeljena nada, nije utopija, nego se njezin topos prepoznaje kao nutarnji prostor samoga Božjega bića.

Iz svega navedenoga postaje razvidno da se takvo teološko promišljanje prostora (prostornost u Bogu i Bog u prostoru) nikako ne može shvatiti kao nesuglasje s Božjom transcendentnošću nad kojom je trajno bdjela kršćanska teologija. Stvorenje egzistira u Božjoj nazočnosti i živi od te nazočnosti, a ta ga nazočnost, iako neizrecivo bliska, uvijek nedokučivo nadilazi. Takvim je promišljanjem Božja transcendentnost upravo naglašena jer se nazočnost Boga u stvorenju ne misli panteistički niti nazočnost stvorenja u Bogu kao dokidanje stvorenjske ograničenosti, konačnosti, odnosno kao uspostava identiteta po kojem bi stvorenje bilo izjednačeno sa Stvoriteljem. Upravo suprotno, nazočnost Boga u stvorenju i stvorenja u Bogu uz njihovu trajnu i nedokidivu različitost moguća je jedino unutar naglašene Božje transcendentnosti, moguća je jedino snagom božanske ljubavi i kao čudo te ljubavi.

\section{Zaključak}

Vidjeli smo da je primarno okretanje kategoriji vremena i povijesti, kao osobitost starozavjetne, ali dugo vremena i kršćanske vjerničke tradicije, temeljeno na osjetljivosti za Božju transcendentnost i nužnom razlikovanju Boga i svijeta. Ipak, za razliku od starozavjetnoga bogoiskustva koje se očitovalo kao iskustvo suživota $s$ Bogom i iskustvo njegove izravne upletenosti u ljudsku povijest i ljudske sudbine, na što je ipak upućivalo naglašavanje njegove trajne nazočnosti u Izraelu (Kovčeg zavjetni, hram, šekinah), kršćanska je teologija pitanje Boga i njegova odnosa sa svijetom dugo vremena postavljala odviše metafizički. Postavljalo se i pokušavalo odgovoriti na ontološka pitanja o Božjem bitku ili egzistenciji, nerijetko zaboravljajući na egzistencijalno pitanje Božje nazočnosti u svijetu i ljudskoga iskustva te nazočnosti i povjerenja u nju. Pri tom se zaboravljalo da upravo iz te egzistencijalne

${ }^{55}$ J. MOLTMANN, Trinität und Reich Gottes, 229.

${ }^{56}$ Moltmann će za to eshatološko međusobno nastanjenje Boga i njegova stvorenja jednoga u drugome upotrijebiti izraz $\gg$ kosmische communicatio idiomatum «. J. MOLTMANN, Das Kommen Gottes, 337. 
perspektive temeljno vjerničko pitanje jest pitanje unutar kategorije prostora. Je li Bog ovdje, odnosno gdje je Bog? Štoviše, čini se da se u pitanju gdje sažimaju i sva druga pitanja o Bogu.

Moltmannova je teologija dobar primjer kako kršćanska teologija, iako tradicionalno naglašenije okrenuta kategoriji vremena, u novijem vremenu uz kronološko postaje sve svjesnija i topološkoga pitanja te traga za razumijevanjem prostora kao kategorije u kojoj bi se bez pridržaja moglo prihvatiti i navijestiti polazište biblijskoga iskustva Božje blizine: Bog je ovdje za nas. Vidjeli smo da je on relevantnost kategorije prostora u njezinu punom smislu otkrio u svojoj teologiji stvaranja, promišljajući svijet kao Božje stvorenje, ali je istinska teološka uporišta za zaokret prema promišljanju prostora pronašao u trinitarnoj teologiji. Zahvaćanje u kategoriju prostora kao teološkoga mjesta pokazalo se tako kao njegovo vjerničko-teološko razumijevanje egzistencijalne situacije suvremenoga čovjeka i odgovornosti pred nužnošću teološkoga navještaja tom čovjeku. On uviđa da se taj navještaj ne ostvaruje polazeći od filozofskih pojmova najuzvišenijega bitka ili apsolutnoga subjekta, stoga u svojoj teologiji polazi od novozavjetnoga iskustva Boga kao trojstvenoga zajedništva koje je u sebi ljubav, a onda i ljubav za svijet. U istinskom uvjerenju da je trojstveni Bog spasenje čovjeka on promišljanje Božjega trojstvenoga bića želi spustiti s metafizičke na egzistencijalnu razinu i tako Božju trojstvenost pokazati kao onu koja se bezuvjetno tiče čovjeka i njegova spasenja.

Učinio je to povlačeći poveznice s kabalističkim naukom o Bogu, ali prije svega s pomoću otačkoga pojma trinitarne perihoreze, promišljajući nutarnje Božje biće kao prostor, odnosno trojstvene osobe kao životne prostore jedne za drugu. Takvo $\mathrm{mu}$ je promišljanje pružilo uporište i za promišljanje perihoretskoga prožimanja Boga i svijeta, odnosno od Boga žuđeno nastanjenje u njegovu stvorenju i stvorenja u Bogu. Pri tom je Moltmannu jasno da pojam perihoreze nije ni konačan ni potpun pojam za izricanje Božjega trojstvenoga bića. No on to, prema Moltmannu, i ne mora biti. Štoviše, budući da je teologija ljudsko izricanje Boga, nije to nijedan teološki izričaj. Teologija se, kako to pokazuje i povijest teologije, a Moltmann je toga itekako svjestan, uvijek mora truditi biti jedinstven i neprekinut dijalog sa svojim vremenom i svijetom, dijalog u kojem svaka nova generacija pronalazi odgovore na teološka pitanja i tako uvijek iznova tom svijetu posreduje kršćansko iskustvo i uvjerenost u istinu vjere ${ }^{57}$, dakle bitno je obilježena relativnošću u odnosu na Apsolutno koje propituje. Dakako da ta oznaka relativnosti vrijedi i za Moltmannovu teologiju, na kojoj se jasno prepoznaje njezino vremensko, prostorno i konfesionalno određenje i sva uvjetovanost koja iz tih određenja proizlazi. Iako duboko određen njemačkom protestantskom teologijom druge polovice 20. stoljeća (na liniji

${ }^{57}$ Usp. J. MOLTMANN, Trinität und Reich Gottes, XIV. 
K. Bartha i Ispovijedajuće crkve unutar njemačkoga protestantizma), zaokretom prema kategoriji prostora u svom teološkom hodu pokazuje on otvorenu teološku svijest i osjetljivost za vrijeme i prostor u kojima živi te toj konkretnoj zadanosti posreduje uvjerenost svoga kršćanskoga iskustva i teološkoga promišljanja.

Moltmannova uvjerenost da je spasenje svijeta unutartrojstvena ljubav u sebi i u svojoj otvorenosti za svijet u njegovoj je teologiji više nego očita. Unutar te osobne vjerničko-teološke uvjerenosti ${ }^{58}$ spomenuta promjena paradigme i njegov teološki zaokret od kategorije vremena prema kategoriji prostora stoga se i ne mogu nazvati radikalnim zaokretom u smislu mijenjanja glavnoga smjera, nego više dosljednim provođenjem temeljne uvjerenosti kroz nutarnji razvoj njegove teologije. Tako se kategorija prostora kao izrazito soteriološki relevantna pokazala na neki način nosivom kategorijom te teologije, ali i crvenom niti koja tu teologiju u potpunosti prožima i u njoj uvijek iznova izranja. Moltmannov teološki put polazi od egzistencijalnih ljudskih pitanja za spasenjem, a odgovore na ta pitanja pronalazi u nutarnjem biću samoga Boga kao zajedništva trojstvene ljubavi. Pri tom prostor misli ponajprije kao prostornost u samome Bogu, ali i kao unutar Boga otvoreni i ponuđeni životni prostor za punu egzistenciju čovjeka, neke vrste otkupljenu prostornost i određenje onoga konačnoga ljudskoga boravišta i prebivališta koje je odgovor na temeljno pitanje smisla i cjelokupnoga ljudskoga traganja za njim. Božje je biće za njega onaj teološki oikos u kategoriji prostora (zaštićeni prostor spašenosti) koji odgovara terminu kairos u kategoriji vremena. Pronašao ga je promišljajući unutarnji Božji život kao život ljubavi, dakle život božanskoga Trojstva. Stoga će i njegov odgovor na uvijek iznova postavljano ljudsko pitanje gdje je Bog i gdje je spasenje nedvosmisleno biti kršćansko iskustvo Isusa kao Božjega Sina, po kojemu je ljudima otvoren spasiteljski prostor božanskoga Trojstva. To potvrđuju njegove riječi: $\gg \mathrm{U}$ domu Oca mojega ima mnogo stanova. (...) Idem pripraviti vam mjesto.« A do toga mjesta spasenja vodi On, »Put, Istina i Život (Iv 14, 2.6).

\footnotetext{
${ }^{58}$ Ono što kod Moltmanna osobito zadivljuje jest prožetost njegove teologije i životnoga puta. U tom je kontekstu na kraju zanimljivo primijetiti kako je teološki zaokret prema kategoriji prostora snažno obilježio i egzistencijalnu razinu njegova života. Svoju će autobiografiju na kraju nasloviti Weiter Raum (Široki prostor). Pozivajući se na riječi Ps 31, 9: »Moje si noge na prostran put izveo «, svjedoči u njoj o prožetosti teologije i životnoga puta, čiji završetak u kršćanskoj nadi prepoznaje i iščekuje u Bogu kao životnom prostoru čovjeka, ali i svoj ljudski životni tijek pokazuje kao povijest jednoga životnoga prostora koji se živi i dijeli u zajedništvu s drugima. Usp. J. MOLTMANN, Weiter Raum. Eine Lebensgeschichte, Güterslog, 2005.
} 


\title{
THE CATEGORY OF SPACE IN THE TRINITARIAN THEOLOGY OF JÜRGEN MOLTMANN
}

\author{
Marija PEHAR*
}

Summary: Because of its constituent function within the category of history, time has always been a very important and frequently discussed topic in the Judeo-Christian tradition, and later in Christian theology, while the category of space in that same theology has remained more at the periphery of interest. However, in contemporary Christian theology, there is an awakened interest in this category and an attempt to show it as an immanent theological category, as we recognize within it the existential religious question of human search for God's presence and closeness. It is an approach where space is contemplated as a relative dimension in relation to God and man, and on the other hand as a possible characteristic of God's very being. With this argumentation, the question of space has also found its place in the theological explorations of Jürgen Moltmann. He ponders how to contemplate space within the experience of God, that is, how to contemplate and understand God if we try to contemplate space in God and God in space. He explores this issue through his religious-theological openness to the world (clearly visible within his theology of creation), but above all through a consistent internal development of his entire theological thought which is centered and grounded in trinitarian theology, a fact that is recognized and shown in this paper. Moltmann would find some starting elements for his theological reflection on space in the Old Testament understanding of God ( $\gg$ šekinah $\ll$, »makom $\ll$ and $\gg$ zimzum $\ll$ ), as presented in the first part of this paper, while he would find and develop the fundamental grounds for a theological interpretation of the category of space only within the trinitarian Christian doctrine, as presented in the second central part. Here we show that the patristic doctrine of perichoresis has served as Moltmann's main grounds to clearly focus on the category of space as a theological category, which is recognized as the fundamental turning point within his theology. Finally, the third part of the paper presents the consistencies which extend from Moltmann's trinitarian reflections to his theology of creation, and later to Christian eschatology, where the reflection on the category of space holds a very important place. This category has somehow proved to be the fundamental category of his theology, but also the red thread that is always re-emerging, interconnecting and completely permeating and defining that theology.

Keywords: space, time, Trinity, trinitarian theology, Moltmann.

\footnotetext{
* Assoc. Prof. Marija Pehar, Ph. D., Catholic Faculty of Theology, University of Zagreb, Vlaška St 38, 10000 Zagreb, Croatia, m.marijape@gmail.com
} 